УДК 351

DOI: https://doi.org/10.26642/jen-2020-2(92)-95-100

\author{
І.М. Петрів, здобувач \\ Міжрегіональна академія управління персоналом
}

Ю.Ю. Бальцій, к.ю.н., доц.

Начіональний університет «Одеська юридична академія»

\title{
Удосконалення механізмів реалізації функцій Конституційного Суду України як органу державної влади з особливим статусом
}

\begin{abstract}
У статті досліджено функиії органу конституиійної юстиції, їх значення та вплив на функціонування механізму державного управління. Проаналізовано підходи до розуміння функиій, повноважень та компетенції органу конституційної юстиції в системі органів державної влади та аналізу існуючого законодавства з цъього питання. Визначено, щуо у прочесі становлення державності, при організації та діяльності системи органів державної влади, реалізація окремих функиій органу конституційної юстиції дозволяє забезпечити стабільність функиіонування механізму державного управління та рівновагу серед гілок влади.

Метою статті $\epsilon$ дослідження особливостей функиій, що реалізуються органами конституційної юстииії в Україні. Наукова новизна полягає у дослідженні та виокремленні функцій органів конституційної юстиції, визначенні їх системного характеру та значення реалізації функцій органом конституційної юстицї як елемента механізму державного управління.
\end{abstract}

Стабільність функиіонування механізму державного управління, крім того, щзо трунтується на основному законі, значною мірою залежить від внутрішньої рівноваги серед органів державної влади та їх компетениійної самостійності. Разом з тим, через історичні умови та політичний прочес, особливо в державах «молодої демократії», складаються ситуації конфлікту серед державних органів різних гілок влади, порушення основного закону, спроби узурпації влади тощо. У таких умовах орган конституційної юстиції, володіючи винятковим функціоналом та механізмами, забезпечує верховенство права, політичну стабільність та баланс механізму державного управління.

3 огляду на те, щзо орган конституиійної юстиції є особливим державним органом, йому притаманна низка функиій, щзо прямо чи опосередковано відображені в законодавстві. Однак найбільша перевага цього органу в тому, що він необмежений у застосуванні лише законодавчо визначених важелів та механізмів вирімення окремих питань. Розгляд спорів чи тлумачення нормативних актів може здійснюватися ним із позиції базових принципів функціонування держави: верховенства права, пріоритету прав людини і громадянина, демократизму тощи.

У зв'язку із зазначеним, характеристика функцій органу конституціийної юстиції дозволяє зрозуміти специфіку изього органу, його значення та місие в системі органів державної влади. Крім того, иляхом удосконалення функцій органу конституиійної юстиції можливо підвищити ефективність діяльності изого державного органу та забезпечити стабільність функиіонування механізму державного управління.

Ключові слова: функцї̈ органу конституційної юстицї̈; механізм державного управління; конституційна юстиція; орган конституційної юстицій в Украйні; конституційний контроль.

Постановка проблеми. Виокремлення та характеристика функцій органу конституційної юстиції України безперечно є важливим завданням з огляду на визначальну роль цього державного органу в системі державного управління. Необхідність у з'ясуванні функцій конкретного органу, органу конституційної юстиції зокрема обгрунтовується тим, що саме функції найбільш яскраво демонструють специфіку, особливість та унікальність діяльності певного органу.

Зазначеним обумовлюється необхідність аналізу й функцій органу конституційної юстиції в Україні та пошук механізмів їх удосконалення 3 використанням досвіду європейських держав, які можна зарахувати до «молодих демократій». Наведений аналіз функцій дозволить виокремити їх значення у механізмі державного управління та вивчити перспективи удосконалення окремих із них.

3 метою удосконалення діяльності органу конституційної юстиції, важливе теоретичне та практичне значення має виокремлення системи функцій органу конституційної юстиції, дослідження змісту цих функцій та їх характеристики як елемент правового статусу органу конституційної юстиції.

Варто зазначити, що функції органів конституційної юстиції стали предметом наукового дослідження вітчизняних вчених досить давно. Однак слід зазначити, що розбіжності у розумінні змісту поняття «функція» визначають відмінності в уявленнях дослідників стосовно переліку функцій, які реалізуються органом конституційної юстиції. 
Для початку необхідно зауважити, що функції органу конституційної юстиції є обов'язковим елементом його правового статусу як складовий елемент функціональної характеристики. Адже функції органу конституційної юстиції, в тій чи іншій державі, необхідно розглядати як складову правового статусу в комплексі 3 принципами та завданнями, компетенцією, структурно-організаційними особливостями, формами, методами та гарантіями діяльності. Саме за допомогою такого аналізу стає можливим зрозуміти значення та роль органу конституційної юстиції у механізмі державного управління.

Таким чином, питання реалізації функцій органом конституційної юстиції в механізмі державного управління є актуальним з огляду на процес становлення державності та потребує детального вивчення й аналізу. Використання прогресивного досвіду розвинутих європейських держав щодо ефективного функціонування конституційної юстиції в механізмі державного управління - надзвичайно актуальна тема в період докорінних змін в Україні.

Аналіз останніх досліджень та публікацій. Необхідно наголосити на тому, що для розуміння актуальних проблем формування й розвитку механізмів державного управління в Україні варто враховувати відповідні положення наукових робіт вітчизняних вчених-теоретиків у галузі державного управління, конституційного, муніципального права та у сфері економіки: Ю.Бальція [3], І.Гришова [4], О.Копиленко [5] та ін., що стосуються питань елементів та сутності механізмів державного управління.

Метою статті $€$ визначення функцій органів конституційної юстиції в Україні, їх значення в механізмі державного управління та перспективи удосконалення.

Викладення основного матеріалу. Якщо функції судів загальної юрисдикції розуміють як напрями, види і форми діяльності з вирішення правових конфліктів, спорів у сфері цивільного, господарського, адміністративного та кримінального судочинства, що здійснюється лише судами на підставах, у межах та порядку, передбачених Конституцією і законами України, то визначення функцій органу конституційної юстиції, їх видів і ознак залишається дискусійним попри значні здобутки вітчизняної та зарубіжної юридичної науки у вивченні цієї проблеми.

Однак перш ніж звернутися до характеристики системи функцій органів конституційної юстиції, доцільно проаналізувати розуміння та термінологічне визначення такого поняття, як «функції конституційної юстиції». Такий аналіз дасть змогу уникнути розбіжностей у розумінні змісту, який наповнює зазначене поняття, та уніфікувати підхід для подальшої характеристики кожної окремо взятої функції.

Функція державного органу вказує головний напрям його діяльності, шлях до загальної мети. Для вирішення конкретних завдань, що постають на цьому шляху, за органом юридично закріплюються певні потенційні можливості, які окреслюються через вид і міру можливої й належної поведінки (повноваження), сферу iї застосування (предметну підвідомчість) та територію дії (територіальну підвідомчість).

Необхідно звернути увагу на те, що функції органу конституційної юстиції - це основні напрями його діяльності, що реалізуються через призму наданих повноважень.

Однак не варто функції органу конституційної юстиції обмежувати лише повноваженнями, передбаченими законодавством. Адже вони можуть також виражатися в змісті й інших норм, наприклад, функція захисту прав і свобод людини і громадянина.

Незважаючи на те, що функції органів конституційної юстиції були предметом наукових досліджень науковців, вчені не мають єдиної думки щодо правової природи цих функцій. У зв'язку із зазначеним, науковцями запропоновано низку різноманітних функцій, що здійснюють органи конституційної юстиції, виходячи з того чи іншого критерію класифікації.

На сучасному етапі розвитку науки дедалі частіше вчені звертаються до вивчення функцій органу конституційної юстиції. Однак більшість досліджень обмежується аналізом окремо взятих функцій конституційної юстиції. У зв'язку 3 цим, постає необхідність систематизації функцій органу конституційної юстиції та вивчення їх у сукупності. Такий підхід дозволить з'ясувати спільні риси в діяльності органів конституційної юстиції в окремих європейських державах та в Україні і виокремити перспективні напрями удосконалення вітчизняного інституту конституційної юстиції.

У науковій літературі існує підхід, згідно з яким пропонується вирізняти основні та додаткові (неосновні) функції органів конституційної юстиції. Так основні функції органу конституційної юстиції виокремлюються із аналізу нормативно закріплених повноважень органу конституційної юстиції.

Водночас слід звернути увагу на те, що, хоча ця система функцій і обмежена порівняно 3 органами конституційної юстиції інших країн, проте, на перший погляд, вона справляє враження завершеної системи функцій.

3 огляду на те, що функціями органу конституційної юстиції є основні напрями його діяльності, то перелік функцій органу конституційної юстиції буде ширшим, у зв’язку з чим і пропонується виокремлювати, крім основних, додаткові функції. 
Так М.В. Вітрук зазначає, що у процесі діяльність органу конституційної юстиції відбувається сприяння удосконаленню законотворчої роботи, реалізується конституційна відповідальність, надаються експертні висновки 3 конституційних питань тощо. А тому це дає підставу вести мову про наявність додаткових функцій, що здійснюються органами конституційної юстиції [6, с. 244].

Розглядаючи систему функцій конституційної юстиції, М.В. Вітрук виокремлює ті, що безпосередньо пов'язані зі здійсненням повноважень конституційних судів, та функції іншого характеру, під якими розуміються основні напрями впливу правових позицій, що містяться у рішеннях органів конституційної юстиції на різноманітні сторони і сфери суспільного і державного життя. Так до першої групи науковець зараховує функції тлумачення конституції, конституційного контролю, визначення та встановлення компетенції органів публічної влади, захист прав і свобод людини і громадянина та додаткові функції, які пов'язані з дачею експертних висновків і провадженням реєстраційно-установчих операцій, що мають загальнообов'язковий характер [6, с. 245].

До групи функцій іншого характеру вчений зараховує такі функції: соціально-політичну, примирення (третейську), суспільно-економічну, соціальну, теоретико-пізнавальну, прогностичну, виховну, профілактичну та організаційно-управлінську. Зокрема, М.В. Вітрук зауважує, що такі функції іншого характеру притаманні державам молодої демократії [6, с. 244-245].

Крім того, деякі вчені зараховують до функцій Конституційного Суду України такі, як правотворча, арбітражна, управлінська, представницька, міжнародна, політична, економічна, соціальна, духовна, інформаційна, інтеграційна, координаційна, охоронна.

Таким чином, на підставі викладеного матеріалу, слід констатувати, що систему функцій органів конституційної юстиції в Україні складають основні функції, які є конституційно визначеними, та додаткові (неосновні функції), які визначаються за окремими ознаками та за елементами діяльності. Такий підхід дає можливість побудувати єдину систему функцій органів конституційної юстиції та прослідкувати спільні функціональні напрями діяльності конституційної юстиції в Україні та окремих європейських державах.

Варто звернути увагу на твердження В.М. Шаповала про те, що Конституційний Суд України не має прямого зв’язку зі здійсненням правосуддя [7, с. 45]. Під поняттям «правосуддя» необхідно розуміти діяльність компетентного суду, яка здійснюється від імені держави за встановленою законом процедурою та змістом якої є розгляд і вирішення конфліктів або правових питань, що виникають у процесі реалізації норм конституційного, цивільного, кримінального, адміністративного й інших галузей права. Тобто йдеться про делегування функції конституційного правосуддя судам загальної юрисдикції.

Зважаючи на місце, яке посідає орган конституційного контролю у механізмі балансу влад, роль його інструментарію й, насамперед, тлумачення конституції в забезпеченні поділу влади, для такого органу характерна третейська функція. Крім того, властиві органу такого типу миротворча та інтегруюча функції, які визначають його роль як гаранта політичного миру в державі.

Формування державності в державах Східної Європи відбувалося під впливом низки чинників як внутрішнього, так і зовнішнього характеру. Тому в умовах нестійкої державності, дисбалансу гілок державної влади органам конституційної юстиції доводилося шукати досить непростий баланс між ідеальним правовим принципом та оточуючою реальністю. Тобто прагнути до такого оптимального рішення, яке б являло собою максимально можливе здійснення ідеального принципу у конкретних історичних умовах. 3 цього приводу слід зазначити, що перед органами конституційної юстиції держав нової демократії постають спільні правові проблеми перехідного періоду. Зокрема, до таких проблем належать незбалансованість системи розподілу влади, конфліктування законодавчої та виконавчої гілок влади, прогалини в законодавстві, низький рівень розвитку парламентаризму, невідповідність національного законодавства загальновизнаним принципам і нормам міжнародного права, відсутність механізмів реалізації рішень органів конституційної юстиції, низький рівень розробки національних конституційно-правових доктрин.

Таким чином, можна стверджувати, що органи конституційної юстиції в державах Східної Свропи (особливо в державах нової демократії) невідворотно $є$ арбітрами у складних спорах між законодавчою та виконавчою гілками влади, в яких досить часто доводиться доводити незалежність судової гілки влади. Органи конституційної юстиції у таких ситуаціях беруть на себе відповідальність 3 розробки правової доктрини та удосконалюють національне законодавство в руслі його гармонізації із загальноєвропейським правовим простором.

Досить цікаву думку стосовно значення конституційної юстиції на сучасному етапі розвитку державності та права висловлює В.Б. Ковальчук. Зокрема, він зазначає, що змінилася сама концепція ролі конституційної юстиції в житті суспільства та держави. Так із органу, який був покликаний здійснювати лише формально-юридичну функцію, а саме забезпечувати верховенство конституції і утверджувати ієрархію правових норм на чолі саме з конституцією як «основоположною нормою», він перетворився в орган, призначенням якого стало забезпечення функціонування нової ціннісно орієнтованої парадигми права, головна мета якої полягає в забезпеченні свободи особи як головної передумови ефективної 
діяльності держави [8]. Крім того, науковець звертає увагу на те, що у механізмі легітимації державної влади конституційні суди виконують функцію посередника між народом та владою, який, з одного боку, захищає право народу на його волевиявлення, що реалізовується, перш за все, через вибори та референдум, а з другого - здійснює контроль за легітимністю актів органів державної влади [8].

Дійсно, аналіз діяльності органів конституційної юстиції в Україні та державах Східної Свропи вказує на людиноцентристський вектор як пріоритетний напрям у діяльності. Удосконалення чи запровадження інституту конституційної скарги, рішення, що захищають основоположні права людини перед державою, є проявом такої діяльності конституційної юстиції. Також практика функціонування органів конституційної юстиції в Україні та державах Східної Європи доводить, що конституційна юстиція є дієвим засобом врегулювання політичних конфліктів, вагомість рішень якої підтверджується великою довірою зі сторони громадян.

Підтвердженням зазначеного є практика діяльності органів конституційної юстиції держав Східної Європи, яка характеризується різноманіттям та своєрідною специфікою, що відображає дух конституційного судочинства в кожній із держав нової демократії. Так Конституційний Суд Угорщини неодноразово захищав принцип людської гідності, соціально-економічні права, право на життя. Він ставив під сумнів фінансово-податкову політику уряду, спрямовану на скорочення державних розходів. Суд розвивав концепцію соціальних прав, але висказався проти теорії переважного права бувших власників націоналізованого майна (хоча послідовно захищав реституцію) [9, с. 41].

Конституційний Суд Чехословаччини, що проіснував всього вісім місяців, брав участь у вирішення федеративних проблем. В подальшому Конституційний Суд Чеської Республіки неодноразово приймав до розгляду скарги на порушення соціальних прав. На відміну від Конституційного Суду Угорщини він практикував ринковий підхід до вирішення соціальних проблем [10, с. 13]. Конституційний Трибунал Польщі звертався до розгляду питань, що хвилював усіх без винятку жителів країни: право жінок на приватність (справа про аборти) і принцип світської освіти (справа про викладання релігії в державних школах $[11$, с. 47]. Особливістю болгарської конституційної юстиції є те, що розгляд справ ініціювався переважно парламентом. Відтак Конституційний Суд відігравав стабілізуючу роль, вирішуючи конфлікти всередині Законодавчих зборів [12, с. 74].

Варто зазначити, що конституційна юстиція держав Східної Європи повсякчас стикається з безліччю проблем та перешкод. Це пов'язано з тим, що більшість зі східноєвропейських держав є новими демократія, в яких, на відміну від західноєвропейських держав, конституційна юстиція не формувалася в глибоких демократичних умовах. Тому практика конституційного правосуддя відображає нестабільність соціально-політичних процесів, нестандартні моделі судової поведінки, конфлікти 3 виконавчою та законодавчою гілками влади. Як наслідок, виникають досить суперечливі рішення, що продиктовані складністю загальнодержавних політичних процесів або надмірною обережністю суддів.

3 огляду на зазначене вище можна констатувати, що серед науковців немає єдності стосовно визначення функцій конституційної юстиції. У пошуках об'єднуючої ознаки можна говорити про забезпечення стабільності функціонування механізму державного управління як провідний i основоположний напрям у діяльності цього органу як в Україні, так і в державах Східної Свропи.

Що стосується класифікації функцій органів конституційної юстиції, то необхідно зауважити про наявність різних критеріїв, за якими функції об'єднуються у певні групи (наприклад, за об'єктом і сферою діяльності, за способами і видом діяльності тощо). На думку автора, цілком обгрунтовано здійснити розподіл функцій органів конституційної юстиції на дві групи: основні та неосновні (додаткові). Такий підхід дозволить виокремити та проаналізувати провідні функції, що здійснюються органами конституційної юстиції у процесі реалізації їх повноважень. Тобто ті функції, які складають основне наповнення діяльності органів конституційної юстиції. Також виокремлення в окрему групу неосновних (додаткових) функцій дасть змогу охарактеризувати окремі аспекти діяльності органів конституційної юстиції, які реалізуються ними не через призму законодавчо визначених повноважень та $\epsilon$ похідними від них. До основних функцій органу конституційної юстиції в Україні належать: конституційного правосуддя (вирішення спорів про право), конституційного контролю, офіційного тлумачення конституції, функцію захисту прав і свобод людини і громадянина, забезпечення принципу поділу державної влади (арбітражна функція). Необхідно виокремити та проаналізувати функцію розгляду конституційних скарг, яка в окремих державах Східної Європи є основною (Чеська Республіка, Польща), проте зараз не набула визнання та законодавчого втілення в Україні.

Зарахування зазначених функцій до основних відображає вирізнення пріоритетних напрямів діяльності, що характерні для органів конституційної юстиції в Україні та державах Східної Європи.

До групи додаткових (неосновних) функцій варто зарахувати: правотворчу; примирюючу; політичну; соціально-економічну; профілактичну; представницьку; міжнародну; теоретико-пізнавальну; інформаційну; прогностичну; виховну.

Виокремлення зазначених функцій в окрему групу обгрунтовано тим, що вони пов'язані 3 реалізацією законодавчо визначених повноважень лише побічно й здійснюються органами 
конституційної юстиції України та держав Східної Європи додатково. Проте наявність таких функцій свідчить про те, що конституційне правосуддя в державах Східної Європи та в Україні стає потужним засобом динамічного й стабільного розвитку суспільства і держави та поглиблення демократії.

Слід констатувати, що функції органів конституційної юстиції є взаємопов'язаними та утворюють певну систему. У сучасних умовах розвитку науки та наукового мислення саме використання системного підходу до дослідження функцій єдиного органу конституційної юстиції як єдиної цілісної системи надасть можливість згрупувати і впорядкувати знання під час вивчення окремих функцій. Крім того, такий підхід дозволяє глибше та повніше зрозуміти зміст кожної з функцій.

Підводячи підсумок викладеного, можна зазначити, що під функціями органу конституційної юстиції слід розуміти основні напрями діяльності, що реалізуються органом конституційної юстиції через призму його повноважень 3 метою виконання основоположних завдань. Досліджуючи функції органу конституційної юстиції через призму його повноважень, слід сказати про багатогранність кожної окремо взятої функції, оскільки вона може відображатися в декількох повноваженнях.

Висновки. Підводячи підсумки, можна констатувати, що функція державного органу вказує головний напрям його діяльності, шлях до загальної мети. Для вирішення конкретних завдань, що постають на цьому шляху, за органом юридично закріплюються певні потенційні можливості, які окреслюються через вид і міру можливої й належної поведінки (повноваження), сферу іiі застосування (предметну підвідомчість) та територію дії (територіальну підвідомчість).

Функції органів конституційної юстиції - це напрями реалізації (застосування) компетенції на шляху до виконання поставленого перед органом конституційної юстиції завдання через здійснення наданих повноважень. Систему функцій органів конституційної юстиції в Україні складають основні функції, які $\epsilon$ конституційно визначеними, та додаткові (неосновні функціі), які вирізняються за окремими ознаками та за елементами діяльності. Такий підхід дає можливість побудувати єдину систему функцій органів конституційної юстиції та прослідкувати функціональні напрями діяльності конституційної юстиції в Україні у механізмі державного управління.

Слід виокремити такі основні функцій органів конституційної юстиції: конституційного правосуддя (вирішення спорів про право), конституційного контролю, офіційного тлумачення, розгляд конституційних скарг, функція захисту прав і свобод людини і громадянина, забезпечення принципу поділу державної влади (арбітражна функція). Додатковими функціями органів конституційної юстиції можна вважати: правотворчу; примирюючу; політичну; соціально-економічну; профілактичну; представницьку; міжнародну; теоретико-пізнавальну; інформаційну; прогностичну; виховну.

Важливою для функціонування механізму державного управління є третейська функція органу конституційної юстиції, яка виражається в повноваженнях, що спрямовані на усунення дисбалансу гілок державної влади, та створенні балансу між ідеальним правовим принципом та оточуючою реальністю, тобто у виробленні такого оптимального рішення, яке б становило максимально можливе здійснення ідеального принципу у конкретних історичних умовах.

Надважливим для ефективного функціонування механізму державного управління є конституційний контроль рішень і дій вищих посадових осіб держави, організації і діяльності політичних партій та інших громадських об’єднань, що здійснюються органами конституційної юстиції, спрямований як на відновлення конституційності, так і у випадках - на встановлення фактів порушення конституції, конституційної присяги, вчинення тяжких злочинів вищими посадовими особами держави (главою держави, головою уряду, верховним суддею та ін.), антиконституційної діяльності політичної партії, громадського об’єднання, що є підставою (юридичним фактом) для їх відмови від посади (імпічменту), для заборони чи призупинення діяльності політичної партії, громадського об'єднання. Такого роду повноваження конституційних судів передбачені в Болгарії, Молдові, Словаччині, Польщі.

3 огляду на зазначене, необхідно вивчити значення кожної функції органу конституційної юстиції для функціонування механізму державного управління. А використовуючи прогресивний досвід органів конституційної юстиції окремих європейських держав, можливо визначити напрями удосконалення реалізації окремих функцій органом конституційної юстиції в Україні та запропонувати розширення його функціоналу 3 огляду на виклики часу та забезпечення більшої ефективності механізму державного управління.

\section{Список використаної літератури:}

1. Конституція України ; прийнята на п'ятій сесії Верховної Ради України 28 червня 1996 року // Відомості Верховної Ради України. - 1996. - № 30. - 141 с.

2. Про Конституційний Суд України : Закон України від 16 жовтня 1996 року // Відомості Верховної Ради України. - 1996. - № 49. - 272 с.

3. Бальцій Ю. Місцеве самоврядування в контексті діючої Конституції України / Ю.Бальцій // Юридичний вісник. - 2016. - № 2. - С. 117-120.

4. Gryshova I. Lobbying for Public Interests as a Democratic Social Leadership Factor for Reforming Legislation / I.Gryshova, T.Tielkiniena, A.Guliyeva ; in W.Strielkowski (ed.) // Sustainable Leadership for Entrepreneurs and Academics. Springer Proceedings in Business and Economics. - Cham : Springer, 2018. - P. 481-489. 
5. Kopylenko O. The Phenomenon of Leadershipin the Municipal Authorityin Ukraine / O.Kopylenko, M.Baimuratov, I.Gryshova ; in W.Strielkowski (ed.) // Sustainable Leadership for Entrepreneurs and Academics. Springer Proceedings in Business and Economics. - Cham : Springer, 2018. - P. 151-162.

6. Витрук Н.В. Конституционное правосудие. Судебно-конституционное право и процесс / Н.В. Витрук.М. : Юристъ, $2005-527$ с.

7. Шаповал В.М. Проблеми розвитку конституційної юрисдикції в Україні / В.М. Шаповал // Вісник Конституційного Суду України. - 1998. - № 2. - 45 с.

8. Ковальчук В.Б. Конституційна юстиція в механізмі легітимації державної влади: зарубіжний та вітчизняний досвід / В.Б. Ковальчук [Електронний ресурс]. - Режим доступу : http://naub.oa.edu.ua/2009/konstytutsijnayustytsiya-v-mehanizmi-lehitymatsiji-derzhavnoji-vlady-zarubizhnyj-ta-vitchyznyanyj-dosvid/.

9. Минк Андраш Интервью с Председателем Конституционного Суда Ласло Шольомом / Андраш Минк // Конституционное право: Восточноевропейское обозрение. - М., 1997. - № 2 (19). - С. 41-48.

10. Зоммер Бертольд Защита прав человека: прерогатива Конституционного Суда и компетенция судов общей юрисдикции / Бертольд Зоммер // Российская юстиция. - М., 1999. - № 2. - С. 13-14.

11. Грудзинская-Гросс Елена Интервью с Председателем Конституционного Трибунала профессором Анджеем Золлом / Елена Грудзинская-Гросс // Конституционное право: Восточноевропейское обозрение. - М., 1997, № 2 (19) - C. 47-48.

12. Неновски Н. Конституционный суд в Болгарии / Н.Неновски, М.Жабинска // Государство и право. - М., 1993. - № 9. - С. 74-79.

\section{References:}

1. Verhovna Rada Ukrai'ny (1996), Konstytucija Ukrai'ny: pryjnjata na p'jatij sesii' Verhovnoi' Rady Ukrai'ny 28 chervnja 1996 roku, No. 30, 141 p.

2. Verhovna Rada Ukrai'ny (1996), Pro Konstytucijnyj Sud Ukrai'ny, Zakon Ukrai'ny vid 16 zhovtnja 1996 roku, No. 49, 272 p.

3. Bal'cij, Ju. (2016), «Misceve samovrjaduvannja v konteksti dijuchoi' Konstytucii' Ukrai'ny», Jurydychnyj visnyk, No. 2, pp. 117-120.

4. Gryshova, I., Tielkiniena, T. and Guliyeva, A. (2018), «Lobbying for Public Interests as a Democratic Social Leadership Factor for Reforming Legislation», in Strielkowski, W. (ed.), Sustainable Leadership for Entrepreneurs and Academics. Springer Proceedings in Business and Economics, Springer, Cham, pp. 481-489.

5. Kopylenko, O., Baimuratov, M. and Gryshova, I. (2018), «The Phenomenon of Leadershipin the Municipal Authorityin Ukraine», in Strielkowski W. (ed.), Sustainable Leadership for Entrepreneurs and Academics. Springer Proceedings in Business and Economics, Springer, Cham, pp. 151-162.

6. Vitruk, N.V. (2005), Konstitucionnoe pravosudie. Sudebno-konstitucionnoe pravo i process, Jurist', Moskva, 527 p.

7. Shapoval, V.M. (1998), «Problemy rozvytku konstytucijnoi' jurysdykcii' v Ukrai'ni», Visnyk Konstytucijnogo Sudu Ukrai'ny, No. 2, 45 p.

8. Koval'chuk, V.B., Konstytucijna justycija v mehanizmi legitymacii' derzhavnoi' vlady: zarubizhnyj ta vitchyznjanyj dosvid, [Online], available at: http://naub.oa.edu.ua/2009/konstytutsijna-yustytsiya-v-mehanizmi-lehitymatsijiderzhavnoji-vlady-zarubizhnyj-ta-vitchyznyanyj-dosvid/

9. Mink, Andrash (1997), «Interv'yu s Predsedatelem Konstitutsionnogo Suda Laslo Shol'omom», Konstitutsionnoe pravo: Vostochnoevropeiskoe obozrenie, Moskva, No. 2 (19), pp. 41-48.

10. Zommer, Bertol'd (1999), «Zashchita prav cheloveka: prerogativa Konstitutsionnogo Suda i kompetentsiya sudov obshchei yurisdiktsii», Rossiiskaya yustitsiya, Moskva, No. 2, pp. 13-14.

11. Grudzinskaja-Gross, Elena (1997), «Interv'yu s Predsedatelem Konstitutsionnogo Tribunala professorom Andzheem Zollom», Konstitutsionnoe pravo: Vostochnoevropeiskoe obozrenie, Moskva, No. 2 (19), pp. 47-48.

12. Nenovski, N. and Zhabinska, M. (1993), «Konstitutsionnyi sud v Bolgarii», Gosudarstvo i pravo, Moskva, No. 9, pp. 74-79.

Петрів Іван Михайлович - здобувач Міжрегіональна академія управління персоналом.

Наукові інтереси:

- публічне управління та адміністрування;

- державне управління;

- муніципальне та конституційне право;

- механізми реалізації державної влади.

http://orcid.org/0000-0003-2698-395X.

Бальцій Юрій Юрійович - кандидат юридичних наук, доцент кафедри конституційного права Національного університету «Одеська юридична академія».

http://orcid.org/0000-0003-0331-9810. 